\title{
The Choice Between Single-Unit And Multi-Unit Franchising: Combining Agency And Transaction Cost Perspectives
}

\author{
Dildar Hussain, ESC Rennes School of Business, France
} Lindia Moritz, University of Vienna, Austria

Josef Windsperger, University of Vienna, Austria

\begin{abstract}
This study investigates the factors explaining the franchisor's choice between single-unit and multi-unit franchising based on agency theory and transaction cost theory. We examine the impact of behavioral uncertainty due to shirking and free-riding, franchisees' transaction-specific investments, and environmental uncertainty on the franchisor's choice of multi-unit franchising. Our empirical results from the German franchise sector provide strong support of the transaction cost hypotheses and relatively weak support of the agency-theoretical hypotheses. This study contributes to the literature by showing that the transaction cost explanation complements the agency cost explanation of multi-unit franchising.
\end{abstract}

Keywords: Multi-Unit Franchising; Agency Theory; Transaction Cost Theory Transaction-Specific Investments; Environmental Uncertainty

\section{INTRODUCTION}

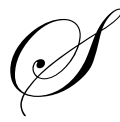

ince the 1980s, a major proportion of the growth in franchising business can be attributed to the advent of a new governance form, i.e., multi-unit franchising (MUF) (Dant, Weaven, Baker, \& Jeon, 2012; Gillis, McEwan, Crook, \& Michael, 2011). MUF refers to an organizational setting where one franchisee owns two or more units in the same franchise system. On the other hand, traditional franchising is primarily characterized by single-unit franchising (SUF), where one franchisee owns only one unit in the franchise system. According to the resource scarcity theory, the main arguments for using MUF are faster system growth, higher firm survival when new franchising units are assigned to existing franchisees and the ability to overcome financial and human resource scarcity, faced by the franchisor (Kaufmann \& Dant, 1996). Moreover, multi-unit franchisees are more likely to follow standardized procedures and routines as compared to single-unit franchisees, thus systems emphasizing uniformity have a higher proportion of MUF (Garg, Rasheed, \& Priem, 2005).

According to the agency theory, MUF will be chosen to alleviate agency problems due to shirking and freeriding (Bercovitz, 2004; Brickley, 1999; Gomez, Gonzalez, \& Vazquez, 2010; Jindal, 2011; Kalnins \& Lafontaine, 2004). MUF enables the franchisor to reduce monitoring costs by delegating control of outlets to multi-unit franchisees (Blair \& Lafontaine, 2005). Compared to SUF, area managers employed by the franchisor are replaced by non-shirking agents (i.e., multi-unit franchisees) who are residual claimants (Jindal, 2011). These mini-chain owners have strong entrepreneurial incentives both to pursue growth and monitor closely their unit-level managers. Consequently, the multi-unit franchisee as residual claimant has the control rights over certain number of outlets in the mini-chain resulting in a reduction of the internal hierarchy compared to a single-unit franchise system (Garg, et al., 2005). In addition, MUF reduces the incentives for free-riding compared to SUF. 
This study applies agency and transaction cost theory to explain the use of MUF in the German franchise sector. According to the agency theory, we hypothesize a positive effect of behavioral uncertainty due to shirking and free-riding on franchisor's use of MUF. Based on transaction cost theory, we hypothesize a positive effect of franchisee's transaction-specific investments and a negative effect of environmental uncertainty on the franchisor's use of MUF. This research contributes to the literature by using transaction cost theory to complement the agencytheoretical explanation of MUF. Specifically, the results from the German franchise sector show that the transaction cost variables have a greater explanatory power than the agency-theoretical variables.

This study is divided into five sections. Section two presents theory and hypotheses, sections three and four present the methodology and results, while discussion and conclusion are appended in the last section.

\section{THEORY AND HYPOTHESES}

\section{Free-riding and Shirking}

Agency theory focuses on solving incentive problems between the agents in intra- and interorganizational relationships (e.g., employer and employee and franchisor and franchisees) (Blair \& Lafontaine, 2005). According to the agency theory in franchising (e.g., Brickley, Dark, \& Weisbach, 1991; Lafontaine, 1992), agency costs result from behavioral uncertainty due to free-riding and shirking of the network partners. MUF provides a mechanism to control free-riding by franchisees, provided that the units are geographically close (Jindal, 2011). In this case, franchisees will bear at least some of the costs if quality standards are not maintained (Gomez, et al., 2010). System uniformity as a crucial input to maintain brand name capital will lead to a higher use of MUF combined with lower incentives for free-riding, because multi-unit franchisees bear greater detrimental effects when they offer lower quality products or services (Garg, et al., 2005). Hence we can formulate the following hypothesis:

H1: The use of multi-unit franchising in a franchise system is positively related with the brand name value.

Another important reason for franchising, from an agency theory perspective, is to efficiently tackle the monitoring problems of geographically dispersed units (Watson, Stanworh, Purdy, Healeas, \& Holden, 2007). The multi-unit franchisee as residual claimant may help to reduce monitoring costs that arise under the internal hierarchy due to the shirking of the employed area managers (Jindal, 2011). In addition, some of the monitoring tasks are delegated to the multi-unit franchisees (Watson, et al., 2007). Consequently, under MUF, a more efficient control at the store level can be expected. We predict that MUF reduces shirking-based monitoring costs.

H2: The use of multi-unit franchising in a franchise system is positively related with monitoring costs due to shirking.

\section{Transaction-specific Investments}

Transaction cost theory regards transaction-specific investments and environmental uncertainty as the major influencing factors of governance mechanism (Klein, 1980, 1995; Manolis, Dahlstrom, \& Nygaard, 1995; Williamson, 1975, 1979, 1985). Franchisors expect franchisees to undertake significant commitments through investments in transaction-specific assets. These transaction-specific investments bond the franchisee to the franchise system and offer a source of leverage to ensure ongoing cooperation between the network partners (Combs $\&$ Ketchen, 1999). Due to coordination economies of scale at the mini-chain level, franchisees' transaction-specific investments per outlet decrease with the number of outlets in a mini-chain, resulting in a stronger bonding effect compared to SUF. Especially for area development franchisees, the potential loss of the higher quasi-rent stream provides a higher incentive to act cooperatively (Garg, et al., 2005). In this way, MUF increases the self-enforcing range of contracts, because the franchisee's expected quasi-rent stream will more likely to exceed his/her short-run gains from opportunistic behavior (Klein, 1995). Furthermore, if franchisees obtain multi-unit opportunities, the self-enforcement effect will be stronger, and the franchisor will be less forced to employ disciplinary measures, like system termination (Bercovitz, 2003). Consequently, we can predict that the stronger bonding effect of franchisees' transaction-specific investments under MUF compared to SUF positively impacts the propensity to use MUF. 
H3: The use of multi-unit franchising in a franchise system is positively related with franchisees' transactionspecific investments.

\section{Environmental uncertainty}

Environmental uncertainty reflects the difficulty faced by the franchisor to predict the market development at the local outlets. Under SUF, the franchisee is likely to have higher entrepreneurial skills and incentives to be responsive to variations in the local market environment than the outlet manager in a mini-chain. Hence, we predict that the higher the environmental uncertainty, the more important are the entrepreneurial capabilities and incentives to exploit the local market opportunities (Garg, et al., 2005), and the lower will be the tendency toward MUF.

H4: The use of multi-unit franchising is negatively related with environmental uncertainty.

\section{METHODOLOGY}

\section{Data}

The data are collected through a mail survey of the German franchise systems. We used the directory of the German franchisors for initial short listing of the systems. This directory lists all relevant information about 837 franchise systems operating in Germany. The franchisors' information includes: company name, year established, address, contact person, telephone and fax numbers, short description of business, number of franchised units, number of company-owned units, capital requirements for a franchise (including cash investment, total investment, and minimum net worth), and fee structure (including initial fee, royalty, and advertising fee). A first screening of the data was undertaken by selecting franchisors that provided full information about contact person, contact address, number of franchised and company-owned outlets and the year when they started to franchise. Second, we short listed the franchisors with at least five units or they should have been franchising for at least two years in Germany. The questionnaires were sent to the CEOs or Director Franchising of 491 franchise systems that met our criteria. A follow up questionnaire was also sent through email to the franchisors after three weeks of the first mailings. In the third stage, the franchisors who had not responded yet were contacted by telephone. We received back 137 useable responses resulting in a response rate of around 28\%. The average age of the responding franchise systems was 11 years and the average size of franchise systems included in our sample was 157 units. Non-response bias was estimated by comparing early versus late respondents (Armstrong \& Overton, 1977), where late respondents serve as proxies for non-respondents. No significant differences emerged between the two groups of respondents. In addition, we checked for common method bias. Based on Podsakoff et al. (2003), we used Harman's single-factor test to examine whether a significant amount of common method variance exists in the data. Common method bias could not be corroborated.

\section{Measurement}

\section{Dependent Variable}

The dependent variable, intensity of multi-unit outlets (IntMUF), is measured as a ratio of franchised outlet to the number of franchisees. A similar ratio has been used in previous studies (e.g., Bercovitz, 2003; Gomez, et al., 2010) as an indicator for MUF. However, some studies use dichotomous measures for the use of MUF (e.g., Bradach, 1995)

\section{Predictor Variables}

Shirking (SHIR) and Free-riding (FRD): Shirking leads to high monitoring costs. Adapted from John and Weitz (1988), franchisors were asked on a two-item seven-point scale to indicate how much difficult it is to assess capabilities and performance of the local outlet managers. Cronbach's alpha is 0.778 . On the other hand, free-riding is related to the brand name of the franchisor. If a franchisor's brand name is of high value, the franchisor will face a higher risk of free-riding. Franchisors were asked to indicate (on a three-item seven point scale) how important their brand name is in terms of recognition and strength compared to their competitors, and competitive advantage (e.g., Barthélemy, 2008). Cronbach's alpha is 0.761 . 
Environmental Uncertainty (CERT) and Transaction-specific Investments (INV): Environmental uncertainty is measured by two items (e.g., John \& Weitz, 1988): "The sales at the outlet level are very fluctuating"; and "It's very difficult to predict the market development at the outlet level". Cronbach's alpha is 0.817 . To measure transaction-specific investments of the franchisee, the franchisors were asked to indicate (on a two-item seven-point scale) to what extent franchisees have to bear transaction-specific investments (expenses for technical and organizational support and expenses for initial training) at the beginning of the contract period. This scaling is compatible with the items used in industrial purchasing relationships (Heide \& John, 1988, 1990). Cronbach's alpha is 0.783 .

\section{Control Variables}

Two control variables have been included in the regression analysis: System size (SIZE) and age of the system (AGE). The size of the system is measured by the total number of franchised and company-owned outlets. Larger franchise systems signal a higher level of strength and success of the system and are more attractive for the prospect multi-unit franchisees. The existing research suggests a positive effect of system size on the use of MUF (Gomez, et al., 2010; Weaven \& Herington, 2007). The age of system was defined by the number of years since the system has started franchising in Germany. Previous research supports the view that older franchise systems are more likely to use MUF because in an early stage of their life cycle they do not possess the reputation to attract multi-unit franchisee candidates (Weaven \& Frazer, 2007a).

\section{RESULTS}

Correlations are reported in Table 1. The results do not indicate concerns about multicollinearity.

Table 1: Descriptive Statistics

\begin{tabular}{|c|c|c|c|c|c|c|c|c|c|c|}
\hline \multirow{2}{*}{\multicolumn{2}{|c|}{ Variable }} & \multirow{3}{*}{$\begin{array}{c}\text { Mean } \\
1.504\end{array}$} & \multirow{3}{*}{$\begin{array}{l}\text { S.D } \\
1.010\end{array}$} & \multicolumn{6}{|c|}{ Correlations } & \\
\hline & & & & 1 & 2 & 3 & 4 & 5 & 6 & 7 \\
\hline 1. & PropMUF & & & 1 & & & & & & \\
\hline 2. & SHIR & 3.339 & 1.417 & $0.275^{* *}$ & 1 & & & & & \\
\hline 3. & FRD & 5.591 & 1.140 & $0.191^{*}$ & 0.920 & 1 & & & & \\
\hline 4. & INV & 3.600 & 1.817 & $0.240 * *$ & $0.183^{*}$ & 0.120 & 1 & & & \\
\hline 5. & CERT & 3.894 & 1.583 & $-0.328 * *$ & -0.0250 & -0.146 & 0.022 & 1 & & \\
\hline 6. & AGE & 11.190 & 8.391 & $0.286 * *$ & 0.127 & 0.162 & 0.032 & -0.002 & 1 & \\
\hline 7. & SIZE & 155.949 & 328.376 & 0.097 & 0.069 & -0.140 & -0.066 & 0.016 & $0.453 * *$ & 1 \\
\hline
\end{tabular}

** Correlation is significant at the 0.01 level (2-tailed).

* Correlation is significant at the 0.05 level (2-tailed).

The hypotheses were tested using hierarchical regression to estimate the following model:

IntMUF $=\beta_{0}+\beta_{1} \mathrm{SHIR}+\beta_{2} \mathrm{FRD}+\beta_{3} \mathrm{INV}+\beta_{4} \mathrm{CERT}+\beta_{5} \mathrm{SIZE}+\beta_{6} \mathrm{AGE}+\varepsilon$

According to the agency theory, we propose positive effects of behavioral uncertainty due to shirking (SHIR) and free-riding (FRD) on the franchisor's use of MUF. Based on the transaction cost theory, we hypothesize a positive impact of franchisee's transaction-specific investments (INV) and a negative impact of environmental uncertainty (CERT) on the franchisor's use of MUF.

The results of regression analysis are presented in Table 2. We proceed in three steps: According to Model 1, the agency theory hypotheses (H1, H2), which propose positive relationships between the use of MUF and franchisee's shirking and free riding, are partially supported. According to Model 1 , the impacts of the shirking $(\beta=$ $0.230 ; p<0.05)$ and free-riding variable $(B=0.243 ; p<0.05)$ on the use of MUF are significant $\left(R^{2}=0.112\right)$. H3 proposes that franchisee's transaction-specific investments are positively and $\mathrm{H} 4$ proposes that environmental uncertainty is negatively related with the franchisor's use of MUF. As shown in Model 2, the impact of transactionspecific investments $(\beta=0.218 ; \mathrm{p}<0.05)$ and environmental uncertainty $(\beta=-0.335, \mathrm{p}<0.01)$ on IntMUF are 
significant $\left(\mathrm{R}^{2}=0.249\right)$. Model 3 includes both the agency-theoretical and transaction cost variables as well as control variables. The results in Model 3 explained 31 percent of the variance of the IntMUF variable $\left(\mathrm{R}^{2}=0.31\right)$. However, the results also show that the agency cost hypotheses are weakly supported in Model 2 and 3. Further, AGE has a significant positive impact on the use of MUF. This is consistent with the existing studies (e.g., Weaven \& Frazer, 2007b) arguing that experienced firms will more likely use MUF as they possess the reputation to build a multi-unit system. Overall, we can conclude that the data provide strong support of the transaction cost hypotheses and relatively weak support of the agency cost hypotheses.

Table 2: Regression Analysis

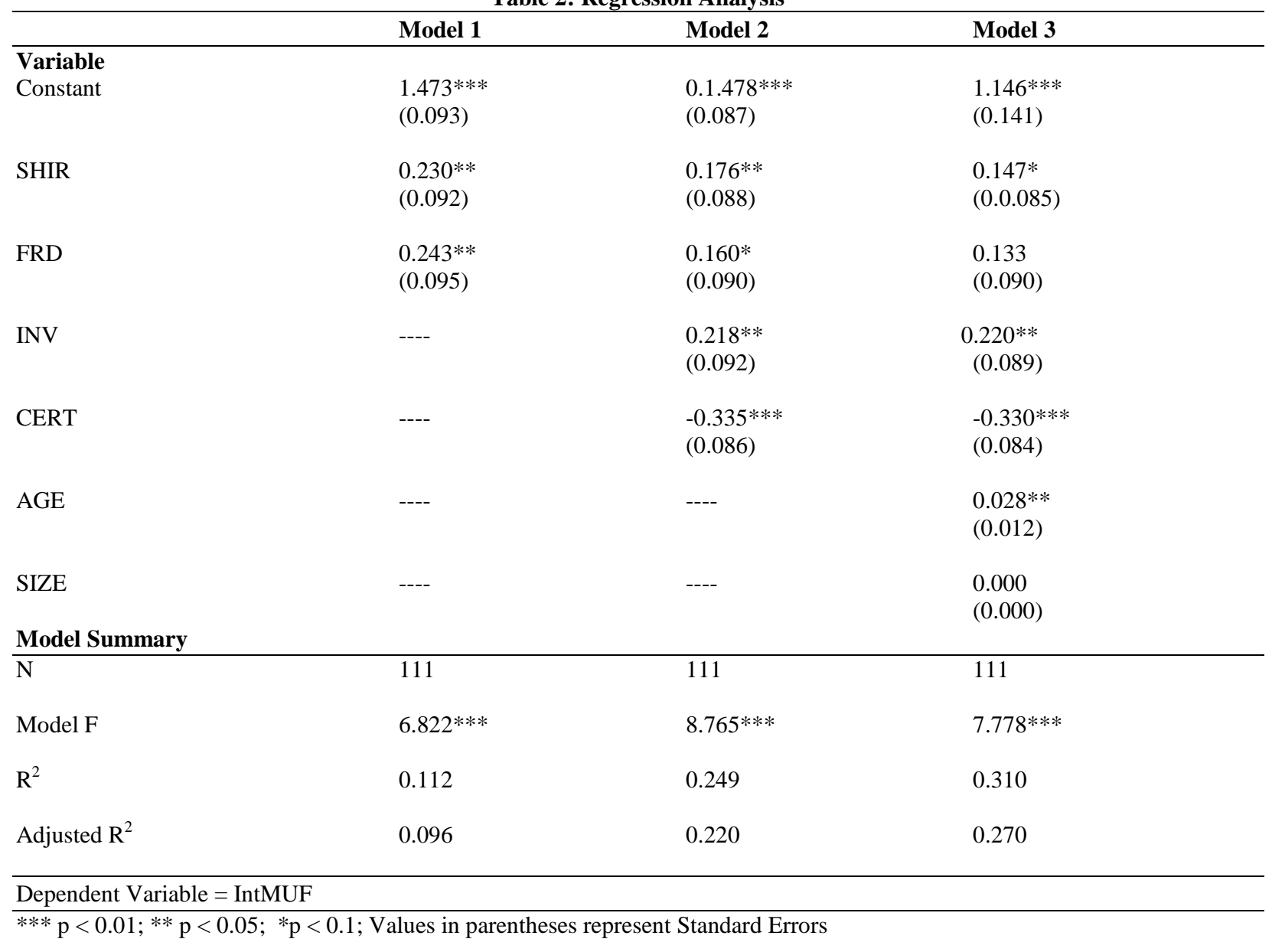

\section{DISCUSSION AND CONCLUSION}

The aim of the study is to explain the franchisor's choice of MUF by applying agency theory and transaction cost theory. According to the agency theory, MUF results in efficiency advantages for the franchisor by reducing the monitoring costs due to shirking and free-riding risk. According to the transaction cost theory, franchisees' transaction-specific investments at the beginning of the contract period have a strong ex-post bonding effect. A greater quasi-rent stream for the franchisee, who operates a mini-chain with multiple units, increases the self-enforcing range of franchise contracts and hence the franchisor's use of MUF. Conversely, the results indicate that the franchisor will use more SUF when the environmental uncertainty is high. Single-unit franchisees have greater entrepreneurial capabilities and motivation to exploit the local market opportunities than the outlet managers of the mini-chains. 
In contrast with previous studies that largely support the agency-theoretical explanations (e.g., Garg, et al., 2005), our data provide relatively weak support of the agency-theoretical hypotheses. Monitoring costs due to shirking as well as the threat of free-riding do not seem to have a strong impact on the franchisor's choice between MUF and SUF. These results rather support the view that MUF represents a curious anomaly in the incentive-based rationale of agency theory (Kaufmann \& Dant, 1996). One possible explanation for the weak support of the agencytheoretical hypotheses in the German franchise sector could be the existence of relatively small and less dispersed franchise systems compared to the U.S. market. In this situation, agency problems due to shirking are less severe. In addition, a further reason might be that the German franchise sector is relatively young, compared with the U.S. franchise sector. Younger franchise systems may have not been able to establish a strong brand name yet (Blair \& Lafontaine, 2005). Therefore, the brand name may be a less valid proxy for free-riding of younger franchise systems. To summarize, our results show that the transaction cost variables have a stronger impact on the use of MUF than the agency-theoretical variables. Overall, this study makes an important contribution by showing that the transaction cost explanation complements the agency cost explanation of MUF.

This study also bears managerial implications for the franchisor's choice of ownership strategy. First, due to the stronger bonding effect of higher transaction-specific investments under MUF compared to SUF, the franchisor can reduce ex-post transaction costs. Second, the franchisor should consider using a higher proportion of MUF in order to cope with monitoring problems due to shirking. Third, contrastingly, in the case of a highly uncertain local market environment, the franchisor should consider using a lower proportion of MUF as the singleunit franchisees can cope with the specifics of the local market environment in a more effective manner than the outlet managers of a mini-chain.

This study is not without limitations. It uses cross-sectional data instead of panel data to explain the franchisor's use of MUF as an ownership strategy. Further this study does not differentiate between the various forms of MUF, such as area development MUF and sequential MUF. Although MUF is assumed to be less effective to respond to local market specifics, there may be significant differences between area development and sequential MUF. Under an incremental or sequential multi-unit contract, a franchisee has higher entrepreneurial capabilities than under an area developer contract. Under such an agreement, a franchisee will more likely emphasize the importance of local responsiveness in the monitoring of outlet managers within the mini-chain as he/she has experience in successfully managing outlets as single-unit franchisee.

\section{AUTHOR INFORMATION}

Dr. Dildar Hussain is an Assistant Professor of Strategy \& Marketing at ESC Rennes School of Business (France). The areas of his research interest include franchising, entrepreneurship, and strategic networks. E-mail: dildar.hussain@esc-rennes.fr (Corresponding author)

Lindia-Maria Moritz was an MBA student at the Center for Business Studies, University of Vienna (Austria). E-mail: lindiamoritz@gmx.net

Dr. Josef Windsperger is an Associate Professor at the Center for Business Studies, University of Vienna (Austria). His research fields are strategy and organization, networks, and theory of the firm. E-mail: josef.windsperger@univie.ac.at

\section{REFERENCES}

1. Armstrong, J., \& Overton, T. (1977). Estimating nonreponse bias in mail surveys. Journal of Marketing Research, 14(August), 396-402.

2. Barthélemy, J. (2008). Opportunism, knowledge, and the performance of franchise chains. Strategic Management Journal, 29(13), 1451-1463.

3. Bercovitz, J. (2003). The option to expand: The use of multi-unit opportunities to support self-enforcing agreements in franchise relationships. Paper presented at the 1st International Conference on Economics and Management of Networks, Vienna. 
4. Bercovitz, J. (2004). The organizational choice decision in business-format franchising: An empirical test. In J. Windsperger, G. Cliquet, G. Hendriske \& M. Tuunanen (Eds.), Economics and Management of Networks (pp. 38-68). New York, USA: Springer Verlag.

5. Blair, R., \& Lafontaine, F. (2005). The Economics of Franchising. Cambridge: Cambridge University Press.

6. Bradach, J. (1995). Chains within chains: The role of multi-unit franchisees. Journal of Marketing Channels, 4(1/2), 65-81.

7. Brickley, J. (1999). Incentive conflicts and contractual restraints: Evidence from franchising. Journal of Law and Economics, 42(2), 745-774.

8. Brickley, J., Dark, F., \& Weisbach, M. (1991). An agency perspective on franchising. Financial Management, 20(1), 27-35.

9. Combs, J., \& Ketchen, D. (1999). Can capital scarcity help agency theory explain franchising? Revisiting the capital scarcity hypothesis. Academy of Management Journal, 42(2), 196-207.

10. Dant, R., Weaven, S., Baker, B., \& Jeon, H. (2012). An introspective examination of single-unit versus multi-unit franchisees. Journal of the Academy of Marketing Science, in press, DOI: 10.1007/s1174711011-10265-11742.

11. Garg, V., Rasheed, A., \& Priem, R. (2005). Explaining franchisors' choices of organization forms within franchise systems. Strategic Organization, 3(2), 185-217.

12. Gillis, W., McEwan, E., Crook, T., \& Michael, S. (2011). Using tournaments to reduce agency problems: The case of franchising. Entrepreneurship Theory and Practice, 35(3), 427-447.

13. Gomez, R., Gonzalez, I., \& Vazquez, L. (2010). Multi-unit versus single-unit franchising: Assessing why franchisors use different ownership strategies. The Service Industries Journal, 30(3), 463-476.

14. Heide, J., \& John, G. (1988). The role of dependence balancing in safeguarding transaction-specific assets in conventional channels. The Journal of Marketing, 52(1), 20-35.

15. Heide, J., \& John, G. (1990). Alliances in industrial purchasing: The determinants of joint action in buyersupplier relationships. Journal of Marketing Research, 27(1), 24-36.

16. Jindal, R. (2011). Reducing the size of internal hierarchy: The case of multi-unit franchising. Journal of Retailing, 87(4), 549-562.

17. John, G., \& Weitz, B. (1988). Forward integration into distribution: an empirical test of transaction cost analysis. Journal of Law, Economics, and Organization, 4(2), 337-355.

18. Kalnins, A., \& Lafontaine, F. (2004). Multi-unit ownership in franchising: Evidence from the fast-food industry in Texas. RAND Journal of Economics, 35(4), 747-761.

19. Kaufmann, P., \& Dant, R. (1996). Multi-unit franchising: Growth and management issues. Journal of Business Venturing, 11(5), 343-358.

20. Klein, B. (1980). Transaction cost determinants of" unfair" contractual arrangements. The American Economic Review, 70(2), 356-362.

21. Klein, B. (1995). The economics of franchise contracts. Journal of Corporate Finance, 2(1-2), 9-37.

22. Lafontaine, F. (1992). Agency theory and franchising: Some empirical results. RAND Journal of Economics, 23(2), 263-283.

23. Manolis, C., Dahlstrom, R., \& Nygaard, A. (1995). A preliminary investigation of ownership conversions in franchised distribution systems. Journal of Applied Business Research, 11(2), 1-8.

24. Podsakoff, P. M., MacKenzie, S. B., Lee, J. Y., \& Podsakoff, N. P. (2003). Common method biases in behavioral research: a critical review of the literature and recommended remedies. Journal of applied psychology, 88(5), 879-903.

25. Watson, A., Stanworh, J., Purdy, D., Healeas, S., \& Holden, R. (2007). Multi-unit franchising: Implications for theory and practice. Paper presented at the 21st Annual International Society of Franchising Conference, Las Vegas.

26. Weaven, S., \& Frazer, L. (2007a). Expansion through multiple unit franchising: Australian franchisors reveal their motivations. International Small Business Journal, 25(2), 173-205.

27. Weaven, S., \& Frazer, L. (2007b). Mature franchise systems use multiple unit franchising to leverage learning economies and sustain systemwide growth. Asia Pacific Journal of Marketing and Logistics, 19(2), 107-126. 
28. Weaven, S., \& Herington, C. (2007). Factors influencing governance choice and human resource management within services franchising networks. Journal of Management \& Organization, 13(2), 126144.

29. Williamson, O. (1975). Markets and Hierarchies: Analysis and Antitrust Implications New York: The Free Press.

30. Williamson, O. (1979). Transaction-cost economics: The governance of contractual relations. The Journal of Law and Economics, 22(2), 233-262.

31. Williamson, O. (1985). The Economic Institutions of Capitalism. New York: The Free Press 